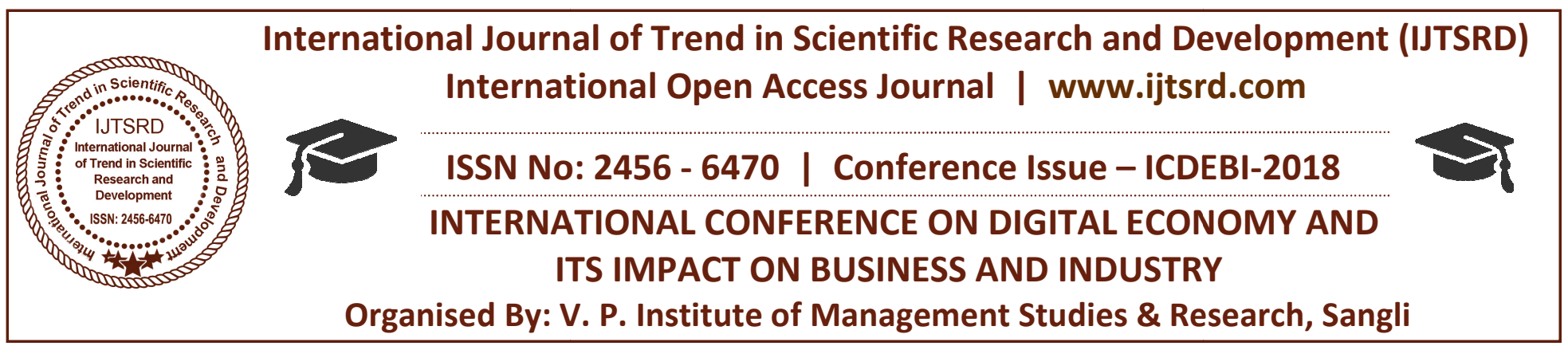

\title{
Customer Satisfaction Towards Paytm in Sangli Miraj Kupwad Muncipal Corporation
}

\author{
Mr. M. M. Samudre, Mr. V. R. Gramopadhye \\ Assistant Professor V. P. Institute of Management Studies \& Research, \\ Sangli, Maharashtra, India \\ Affiliated to Shivaji University, Kolhapur, Maharashtra, India
}

\begin{abstract}
Digital India's drive towards a cashless economy has modernized the launch of Unified Payment Interface (UPI) applications since its launch in Jan 2016. The usage of smart phones as virtual debit cards has doubled to send or receive money instantly. The current study has been conducted in order to meticulously evaluate and examine the level of customer satisfaction towards Paytm UPI app. The purpose of this study is also to observe and analyze the purpose of using Paytm as one of the UPI applications, reasons for choosing Paytm as an UPI application and to find out the problems encountered by the customers. The primary data for this study was compiled through well-structured questionnaire filled in on a one-to-one basis by 150 customers of Sangli Miraj Kupwad Corporation. The study results clearly in dicates that the majority of the users of Paytm UPI application were in the high level of satisfaction. Hence, the study highlights the important points that Paytm UPI application must consider in order to increase the number of users and to improve their service quality.
\end{abstract}

KEYWORD: Paytm, Customer Satisfaction, Unified Payment Interface (UPI).

\section{INTRODUCTION}

Unified Payment Interface is a mobile centric, real time interbank payment system which has the potential to transform and universalize digital payments in India. UPI is a system that powers multiple bank accounts into a single mobile application (of any participating bank), merging several banking features, seamless fund routing \& merchant payments into one hood. It also caters to the "Peer to Peer" collect request which can be scheduled and paid as per requirement and convenience. In August 2016, NPCI launched Unified Payment Interface (UPI), a next generation mobile based payment system which enables real time bank payments thus making smart phone as a primary payment device for both consumers and merchants and to universalize digital payments in the country. The UPI interface will allow account holders across banks to send and receive money from their smart phones using just their Aadhaar unique identity number, mobile phone number or virtual payments address without entering bank account details.

According to NPCI, so far only 29 banks have agreed to start this service. If your bank is UPI-enabled, you can ask it to connect you to the system. To initiate a transaction, you can use two types of address-global or local. Global address includes your mobile, Aadhaar and bank account numbers. A local address can be a virtual address. Let's say your bank gives you a virtual ID similar to your email ID (for instance, name@ company name). This virtual address will allow you to send and receive money from multiple banks and prepaid payment issuers. Paytm India's largest mobile commerce platform is an Indian commerce shopping website. Since its launch it began to launch various services on the digital platform viz. offering mobile recharge, gas bill, electricity bill, telephone bill payments etc. lately, it offers various facilities such as DTH recharge, insurance facilities to 
wider market place to consumers on its mobile apps and web. Within in a short period of time Paytm has scaled to more than 60 million orders per month. Paytm is an acronym for pay through mobile. It entered through India's E-commerce market in 2014 providing facilities and products similar to online business such as flip kart, Amazon, snap deal etc. Paytm has keep on changing from time to time to its terms and conditions as it is a legal contract between an individual customer, user or beneficiary. Paytm is owned by ONE 97 Communications LTD and headquartered in NOIDA, India in 2010. It is privately held company founded by Vijay Shekar Sharma.

Reserve Bank of India In August 2015, granted Paytm license to launch a payments bank. The Paytm Payments Bank is a separate entity in which founder Vijay Shekhar Sharma will hold 51\% share, One97 Communications holds $39 \%$ and $10 \%$ will be held by a subsidiary of One97 and Sharma. The bank was officially inaugurated in November 2017 by the Indian Finance Minister, Arun Jaitley. The inauguration ceremony featured prominent banking personalities including former RBI Executive Director PV Bhaskar, Saama Capital Director Ash Lilani and former Shriram Group Director GS Sun darajan. Vijay Shekhar Sharma and Renu Satti (resigned) (CEO Paytm Payments Bank) are the other directors of Paytm Payments Bank. Its target is to launch over 100,000 banking outlets across India by end of 2018 .

Paytm in 2017 became India's first payment app to cross over 100 million app downloads, with bonanza offer of Paytm Gold, a product that allowed users to buy as little as $\square 1$ of pure gold online. It also launched the Paytm Payments Bank and 'Inbox', a messaging platform with in-chat payments among other products. By 2018, it allowed merchants to accept Paytm, UPI and Card payments directly into their bank accounts at $0 \%$ charge followed by 'Paytm for Business' app, allowing merchants to track their payments and day-to-day settlements instantly. This led its merchant base to grow to more than 7 million by March 2018.Paytm launched its Paytm Mall app in February 2017, which allows consumers to shop from 1.4 lakh registered sellers raised a whopping \$200 million from Alibaba Group and SAIF Partners in March, 2018.

\section{Need For the Study:}

Demonetization drive paved way for Unified Payment Interface (UPI) app through Paytm which was promptly promoted by the government. However, the issue of ease of use, transaction delay, security \& privacy issues cropped up. Currently, Paytm holds $38 \%$ market share in UPI apps. Despite the issues the researchers were interested to know the level of satisfaction derived while using, promoting the Paytm app. and why it's still the unique choice among its rivals.

\section{Literature Review:}

Paytm highlighted that brand reposition is based on allied belief (Haugtvedt et al., 1994) while designing, working and developments of Paytm which consolidated an examination on organizing a store, web progression, online gadget and also depicted about electronic portion system (Shwetu Kumar, Vijay Yadav, Atiqu-Ur-Rahman, Aditi Bansal, 2014) FE Bureau (2017).

There is a bright future for m-payment (Bamasak) as Demonetization has increased the growth of Paytm \& Mobikwik (FE Bureau 2017) which is known as the Digital payment companies. Considering security in mobile payments, independent security was not a primary driver of mobile payment acceptance (Pousttchi and Dietmar G. Wiedemann2008)

\section{Statement of the problem:}

The UPI interface will allow account holders across banks to send and receive money from their smart phones using just their Aadhaar unique identity number, mobile phone number or virtual payments address without entering bank account details. Hence by considering the UPI features, the study of users in Sangli Miraj Kupwad Muncipal Corporation is conducted to determine customer satisfaction towards Paytm in terms of Unified Payment Interface (UPI) apps.

\section{Title of Research:}

Customer Satisfaction towards Paytm in Sangli Miraj Kupwad Muncipal Corporation,

\section{Significance of study}

The research was conducted to analyze the usage of Paytm by users and to study their satisfaction levels based on different parameters viz. Convenience, Safety and Security, Transaction time and Customer service etc.

\section{Objectives of the research:}


1. To find out the level of customer satisfaction towards Paytm (UPI)apps.

2. To study the acceptance level of Paytm in Sangli Miraj Kupwad Corporation as an alternative to the cash transactions.

3. To study the role played by Paytm in Sangli Miraj Kupwad Corporation in supporting growth towards Digital India.

\section{Hypothesis}

$>$ H0:There is no significant relation between security concern and transaction performed on Paytm.

> H1: There is significant relation between security concern and transaction performed on Paytm.

\section{Research design:}

The current study is based on primary data collected from 150 respondents from the different parts of Sangli Miraj Kuwad municipal corporation, Maharashtra. A well-structured questionnaire was designed to collect the information from the respondents the questionnaire was designed to study perception of customer towards adoption of digital payment mode. Likert five point scales were used for obtaining responses. The responses have been collected by means of face-to-face interviews by authors.

\section{Sampling unit:}

In this research the sampling unit was the customers who have been using the digital payment modes through their smart phones.

\section{Sample size:}

For the survey the sample size decided was 150.

\section{Sampling procedure:}

The researchers adopted convenient sampling method for collection of primary data, as it is not possible to take appointment from a large number of respondents. Purpose of this research was told to respondents and questions were explained to them in case there was any need for understanding any particular question. There had been no personal bias or distortions were allowed while recording the responses.

\section{Research and Statistical Tools Employed:}

Age of the person transacting through Paytm app, Is one of the important parameter in determining the satisfaction level due to the level of knowledge, technological knowhow, work experience which influence the different services offered by the app. hence its includes as prime indicator for satisfaction level. The distribution of respondents in years is shown in Table 1.Its observed that more than half of the respondents below 35 years transact through Paytm app. The least age group transacting through Paytm app. is above 60 years.

Table 1: Age of the Respondents

\begin{tabular}{|l|c|c|}
\hline Age in Years & Frequency & Percentage \\
\hline Below 35 & 85 & 57 \\
\hline $36-60$ & 50 & 33 \\
\hline Above 60 & 15 & 10 \\
\hline Total & 150 & 100 \\
\hline
\end{tabular}

Since gender shapes the knowledge, ability to use Paytm services and compare it with its rivals in terms of satisfaction guaranteed it $\mathrm{s}$ included as one of the parameter. The classification of respondents based on gender is depicted as below; the male respondents are the major users of Paytm app. as compared to the female counterparts.

Table 2: Gender of the Respondents

\begin{tabular}{|l|r|r|}
\hline Gender & Frequency & Percentage \\
\hline Male & 95 & 63 \\
\hline Female & 55 & 37 \\
\hline Total & $\mathbf{1 5 0}$ & $\mathbf{1 0 0}$ \\
\hline
\end{tabular}

The frequency of using Paytm app. clearly indicates their product offerings and services offered hence, it $\mathrm{s}$ used as a major parameter to measure their satisfaction level. The distribution of respondents is highlighted as below; It has been observed that major frequency of Paytm usage is monthly constituting $67 \%$ to the total usage followed by the least usage on daily basis i.e. $3 \%$.

Table 3: Frequency of Paytm usage

\begin{tabular}{|l|r|r|}
\hline Usage & \multicolumn{1}{|c|}{ Frequency } & \multicolumn{1}{|c|}{ Percentage } \\
\hline Daily & 5 & 3 \\
\hline Weekly & 45 & 30 \\
\hline Monthly & 100 & 67 \\
\hline Total & $\mathbf{1 5 0}$ & $\mathbf{1 0 0}$ \\
\hline
\end{tabular}

The purpose of using Paytm app. is classified into recharge, ticket booking, bill payment, shopping 
online as given below; Majority of the respondents use Paytm for recharge of mobile i.e. $37 \%$ followed by ticket booking $20 \%$, online bills payment $28 \%$, online shopping $15 \%$ respectively.

Table 4: Purpose of using Paytm.

\begin{tabular}{|l|r|r|}
\hline Purpose & Frequency & Percentage \\
\hline Recharge & 55 & 37 \\
\hline Ticket booking & 30 & 20 \\
\hline Bill payment & 42 & 28 \\
\hline Online Shopping & 23 & 15 \\
\hline Total & $\mathbf{1 5 0}$ & $\mathbf{1 0 0}$ \\
\hline
\end{tabular}

behavior in terms of the amount spent as given below; Majority of the respondents have spent between Rs. 101 to 1000 only which indicates $51 \%$ of the total in comparison to above Rs.2000 which comprises the least i.e. $7 \%$ of the total.

\begin{tabular}{|l|r|r|}
\hline Table 5: Average monthly Spending on Paytm \\
\hline Amount (Rs.) & Frequency & Percentage \\
\hline Less than 100 & 23 & 15 \\
\hline 101 to 1000 & 76 & 51 \\
\hline 1001 to 2000 & 41 & 27 \\
\hline Above 2000 & 10 & 7 \\
\hline Total & 150 & 100 \\
\hline
\end{tabular}

The average monthly spending is signified by logging into Paytm malls. It depends upon the buying

\section{Table 6: Level of Satisfaction Based on Different Parameters}

The level of customer satisfaction towards Paytm app has been measured using five significant parameters using Five point Likert scale. The opinions of which are listed below;

\begin{tabular}{|c|c|c|c|c|c|c|}
\hline Variable & $\begin{array}{c}\text { Highly } \\
\text { Satisfied }\end{array}$ & Satisfied & Neutral & Dissatisfied & $\begin{array}{c}\text { Highly } \\
\text { Dissatisfied }\end{array}$ & Total \\
\hline Easy to Download Paytm App & 30 & 62 & 30 & 20 & 8 & 150 \\
\hline Ease to use & 7 & 38 & 85 & 17 & 3 & 150 \\
\hline Bank transfer & 5 & 112 & 25 & 5 & 3 & 150 \\
\hline Less Transaction Time & 12 & 95 & 28 & 10 & 5 & 150 \\
\hline Secured & 20 & 30 & 57 & 28 & 15 & 150 \\
\hline \multicolumn{7}{|c}{ Source: Primary data } \\
\end{tabular}

The high level of satisfaction was recorded in bank transfer followed by less transaction time, ease to download, security. The normal level of satisfaction was recorded in ease to use followed by security, easy to download, less transaction time, and bank transfer. The highly dissatisfied variable were recorded in secured transactions followed by ease to download, less transaction time.

\section{Hypothesis Testing}

$\mathbf{H 0}=$ There is no significant relation between security concern and transaction performed on Paytm.

H1 = There is significant relation between security concern and transaction performed on Paytm.

By applying chi-square test for table 6, the calculated value (p) is 12.94. Similarly table value for chi-square with degree of freedom 12 at $5 \%$ significance level is 21.03. As calculated value is less than table value, hypothesis stating, there is no significant relation between security concern and transaction performed on Paytm, is accepted. It indicates that users use paytm while giving less attention to services provided by paytm.

\section{Major findings:}

$>$ The respondents below 35 years transact frequently through Paytm application.

The male respondents are the major users of Paytm application.

For the respondents of paytm, major frequency usage is monthly.

Majority of the respondents use Paytm for recharge of mobile.

$>$ The majority of transactions performed on paytm are between Rs. 101 to Rs. 1000.

$>$ The high level of satisfaction was recorded in bank transfer followed by less transaction time, ease to download, security.

\section{Conclusion:}

The present research study concludes that the usage of Paytm is only at a satisfactory level. The customers have issues in ease of use, security issues and slow Paytm server in the usage of Paytm. Paytm has to establish a separate wing with trained staff to address 
the issues and problems related to paytm services. The Paytm may initiate necessary action for periodic updation, up gradation and maintenance of both hardware and software and to prevent cases of slow server and complete breakdown of system by having back storages.

\section{References;}

1. "Paytm Payments Bank to open 100,000 Paytm Ka ATM outlets, set to invest Rs 3,000 cr". The Financial Express. 2017-12-05. Retrieved 201804-07.

2. Shukla, T. N., Mobile wallet: present and the future, Vol. 5, No. 3, June 2016 (ISSN 2278 5973). Available: in/vol5no3/vol5no3.6.pdf.

ssijmar.

3. Shwetu Kumar, Vijay Yadav, Atiqu-Ur-Rahman, Aditi Bansal (2014), "A study on Paytm" Guru Gobind Singh Indraprastha University, Delhi.

4. FE Bureau (2017), "Transfer funds from Paytm wallet to Mobikwik or Pay Zapp or even bank account soon; here is what is on agenda", Accessed from https://www.financialexpress.com/economy/transf erfunds-from-Paytm-wallet-to-mobikwik-orpayzapp-oreven-bank-account-soon-here-is-whatis-onagenda/891046.

5. Balan, R., Ramasubbu, N., Tayi, G. (2006) Digital Wallet: Requirements and Challenges. Source: https://apollo.smu.edu.sg/papers/digitalwallet_cas e.pdf

6. Pousttchi, K., Wiedemann, D., (2008, October) what influences consumers' intention to use mobile payments? Source: http://classic.marshall.usc.edu/assets/025/7534.pd.

7. Dahlberg T, Mallat N, Oorni A (2003) Consumer Acceptance of Mobile Payment Solutions-Ease of Use, Usefulness and Trust. The Second International Conference on Mobile Business, Vienna, Austria, pp: 17-25. 